\title{
МИСТЕЦТВОЗНАВСТВО
}

\author{
DOI: https://doi.org/10.32839/2304-5809/2019-8-72-41 \\ УДК 7.03;7:001.12
}

\author{
Филиппова О.Н. \\ Ассоциация искусствоведов (г. Москва)
}

\begin{abstract}
ТВОРЧЕСТВО Л.С. БАКСТА (1866-1924) - МНОГОГРАННОГО ХУДОЖНИКА
Аннотация. Конец XIX - начало XX века - это время чрезвычайно сложное и противоречивое. В искусстве эта пора отмечена поисками нового большого стиля, способного решить художественные задачи эпохи, найти необходимую гармонию искусства и жизни. Стремлением к этому единству полна деятельность многих художественных групп и отдельных мастеров модерна в Европе и в России. В поисках возможного объединения искусств, синтеза их, признается главная роль архитектуры. Выполняются многочисленные проекты монументально-декоративных росписей. Значительное место отводится и вопросам художественной промышленности - области, выдвинутой усилиями мастеров «нового стиля» в число ведущих [3, с. 5]. В это время процветают такие виды искусства, как театрально-декорационное и книжное оформление. Художник становится универсальным мастером, умеющим и делающим все. Одним из таких многогранных художников был живописец Лев Самойлович Бакст (1866-1924), выступающий и как график, архитектор, декоратор и писатель по вопросам искусства.
\end{abstract}

Ключевые слова: творчество Л.С. Бакста, интерес к театру и рисованию, этюды маслом и акварели, активный деятель общества и журнала: «Мир искусства», живопись, графика, оформление выставок, журналов, эскизы костюмов к балетным постановкам, античная тема в творчестве художника.

Filippova Olga
Association of Art Critics (Moscow)

\section{THE CREATIVE WORK OF L.S. BAKST (1866-1924) - AS AN MULTI-FACETED ARTIST}

Summary. The end of the XIX - beginning of the XX century is an extremely difficult and contradictory time. In art, this time is marked by the search for a new great style that can solve the artistic problems of the era, to find the necessary harmony of art and life. The work of many art groups and individual masters of art Nouveau in Europe and in Russia is full of the desire for this unity. In search of possible unification of arts, their synthesis, the main role of architecture is recognized. Numerous projects of monumental and decorative paintings are carried out. A significant place is given to the issues of the art industry - an area put forward by the efforts of the masters of the "new style" among the leading. At this time, flourishing arts such as theater and decoration and book design. The artist becomes a universal master, able and doing everything. No one is surprised if the painter acts as a graphic artist, architect, decorator and writer on art. The new style gives rise to numerous art journals: this is due to the need immediately, immediately to substantiate theoretically achieved. Perhaps never before, the cultural life was not so intense, never wrote about art so much and never about art wrote so many of the artists themselves. In Russia, the beginning of such activities was primarily associated with the Union: "World of art", which will become an artistic phenomenon in Russian culture. It arose almost in contrast to the movement of the Wanderers with their harsh ideological predetermination. Miriskusniki fought for "pure beauty" and saw the future of art in the synthesis of music, words, painting, dance. And the theater was considered the most suitable place where they intended to realize their ideas. At the exhibitions: "the World of art" you could see the works: A.N. Benois, K.A. Somov, V.A. Serov, M.A. Vrubel, M.V. Nesterov, E.E. Lancer and many other significant masters. With the "World of art" was inextricably linked creativity L.S. Bakst versatile decorator, one of the most interesting figures of art Nouveau.

Keywords: the creative work of L.S. Bakst, interest in theater and drawing, oil sketches and watercolors, an active member of the society and the magazine: "World of art", painting, graphics, design of exhibitions, magazines, sketches of costumes for ballet performances, ancient theme in the creative work of artist.

$\Pi$ остановка личность

проблемы.

Творческая Льва Самойловича Бакста была невероятна многогранна. Он работал не только над театральными постановками, но и был выдающимся живописцем, изысканным графиком, блестящим знатоком древних культур. Признанный авторитет в области женской моды, Л.С. Бакст выступал с лекциями по искусству, преподавал в художественных школах, принимал деятельное участие в разработке хореографии к балетам. Подобно А.Н. Бенуа (1870-1960) - художнику, историку искусства, критику, Л.С. Бакст обладал несомненным литературным дарованием (на примере его воспоминаний «Серов и я в Гре- ции») [1, с. 3]. Художественное и литературное наследие мастера было столь велико, что несмотря на пристальный интерес к нему со стороны широкой группы исследователей в течение ста последних лет, оно по-прежнему неисчерпаемо.

Анализ последних исследований и публикаций. В 2016 году исполнилось 150 лет со дня рождения Льва Самойловича Бакста, более трех десятилетий на родине и за границей, творившего во славу русского искусства. Его жизни и творчеству на разных языках мира посвящено множество исследований и воспоминаний [3; 4; 7]. Между тем, наследие этого самого известного в мире участника содружества «Мир искусства» до сих пор подробно 
не изучено: не существует полного каталога его работ, не выявлена и не воспроизведена большая часть заказных портретов, декоративных панно и жилых интерьеров, над которыми он работал во Франщии, Англии и США в 1910-1920-х годах [5, с. 7]. Цель данной публикации, на основе библиографрических источников, раскрыть творчество Л.С. Бакста, проанализировать его работы.

Лев Самойлович Бакст (Розенберг) родился 9 мая 1866 года в городе Гродно. Его детство прошло в Петербурге, в среде, далекой от искусства и совершенно к нему безразличной, что было не редкостью для многих интеллигентных семей того времени. Первые годы его жизни прошли под впечатлением от встреч с дедом (в 1891 году Л.С. Бакст принял его фрамилию).

Изысканность старинных покоев, роскошь обстановки его дома были для Л.С. Бакста едва ли не единственным художественным впечатлением раннего детства, а сам дед - удивительный старик, полный таинственности и очарования, - сохранился в памяти, как воплощение хорошего вкуса. Интерес к театру и рисованию проявился у мальчика рано. Л.С. Бакст с увлечением разыгрывал сочиненные и поставленные им самим пьесы перед своими сестрами, а первое признание, как художник получил в двенадцать лет, когда вышел победителем в конкурсе на портрет В.А. Жуковского (1783-1852), объявленном в гимназии по случаю столетия со дня рождения поэта. Но, отец Л.С. Бакста, и ранее не поощрявший склонности сына к художествам и считавший это увлечение лишь помехой делам и будущей карьере, вовсе запретил ему рисовать. Л.С. Бакст продолжал свои занятия тайком, по ночам. Увидев такое упорство, родные решили обратиться к какому-либо авторитету и просить его высказать свое суждение о способностях Левушки. Рисунки были посланы в Париж известному скульптору М.М. Антокольскому (1843-1902). Они заслужили доброжелательный отзыв: М.M. Антокольский рекомендовал продолжать учение, и, таким образом, художественное образование Л.С. Бакста стало возможным. В 1883 году, расставшись с гимназией, он становится вольнослушателем Академии художеств. Новый ученик, как и положено, рисует гипсы, драпировки, живую модель, но Академия, переживающая пору застоя, может дать ему не так уж много. Работы Л.С. Бакста не вызвали интереса у П.П. Чистякова (1832-1919), самого значительного из тогдашних профессоров. Другой преподаватель, К.Б. Вениг (1830-1908), был равнодушен к своим ученикам и лишь иногда, глядя на этюды Л.С. Бакста, называл его «новоиспеченным Рубенсом» [3, с. 7]. Третий его учитель, Исаак Львович Аскназий (1856-1902), - известный в свое время художник позднеакадемического направления, который приобрел большое мастерство в Дрездене и в Вене (его работы в значительной мере повлияли на воспитанника).

В годы учения Л.С. Бакст встречается с В.А. Серовым (1865-1911), также студентом Академии. Это знакомство, перешедшее затем в дружбу, было едва ли не менее важным для развития Л.С. Бакста, как художника, чем академический курс. В 1887 году Л.С. Бакст принимает участие в конкурсе на серебряную медаль. На конкурсе была предложена тема «Богоматерь, оплакива- ющая Христа» [3, с. 7]. По описанию этой несохранившейся работы можно было предположить, что подчеркнуто приземленная трактовка сюжета и натуралистичность изображения оттолкнули жюри - оно не приняло работу. Считая себя жертвой предрассудков и академического предубеждения, разочарованный Л.С. Бакст покинул Академию. $K$ этому времени относится его знакомство с известным акварелистом Альбертом Николаевичем Бенуа (1852-1936), мастерство и виртуозность акварельной техники которого увлекают Л.С. Бакста и побуждают его к усиленным занятиям акварелью. Значительная часть его работ начала 1890-х годов - это этюды маслом и акварели, но вместе с тем в многочисленных эскизах встречаются самые разнообразные техники - графрит, черный карандаш, уголь, пастель, гуашь. Они еще неровны по качеству, многие из них производят впечатление сухости и скованности. Л.С. Бакст пробует свои силы в бытовом жанре, совершенно отсутствующем в дальнейшем его творчестве: молодой художник не может пройти мимо царящего вокруг него обилия жанровой живописи. Но, большинство его работ - это портреты. Первые из них еще робки и банальны; Л.С. Бакст не идет в них дальше скрупулезной передачи внешнего сходства. Карандашные наброски, в которых сходству уделяется меньше внимания, точны, метки, в них ловко фриксируется поза. Многие работы носят обобщенный характер, более представляя тип, нежели конкретного человека. Эти изображения являются скорее штудиями, чем самостоятельными произведениями. Несколько акварелей 1892 года - «Кармен» (ГТГ), «Испанец» (ГРМ), «Боярыня» (ГРМ), "Украинка» (ГМИИ) - сходны по манере исполнения, композиции, цвету [3, с. 8] (илл. 1).

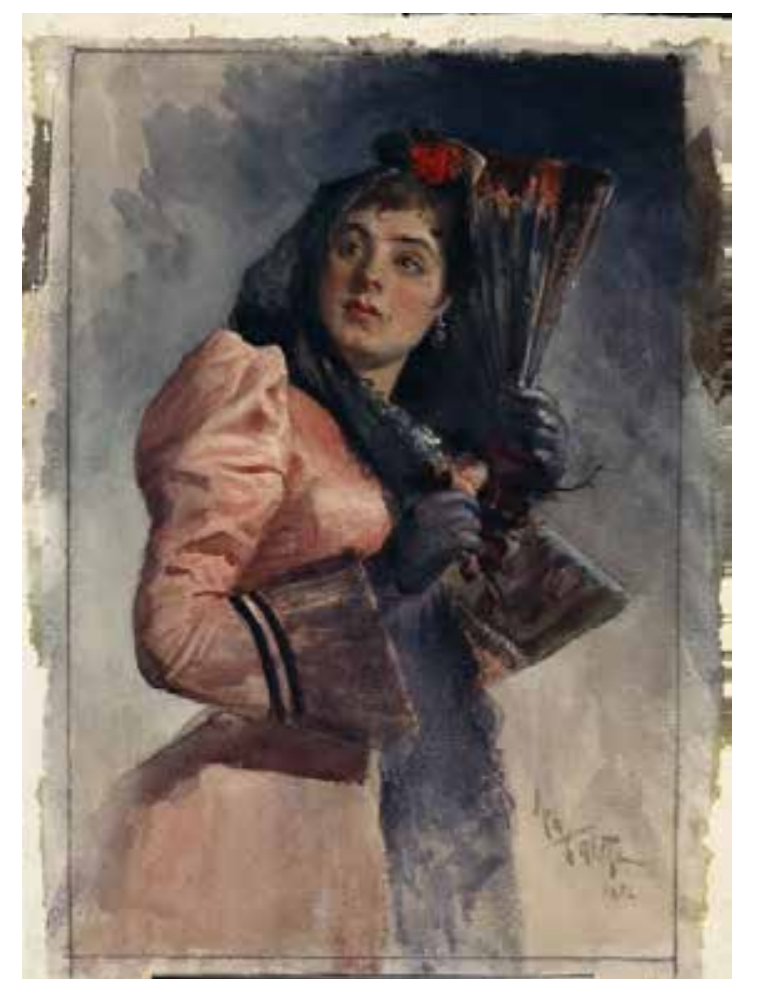

Илл. 1. Л.С. Бакст. «Кармен». 1892 г. Бумага, акварель // Государственная Третьяковская галерея (Москва) 
Яркие, построенные на сочетании розового, синего, черного, они кажутся несколько пестрыми. Позы и жесты нарочито значительны. Лист, целиком заполненный краской, тщательность проработки, выписанные лица говорят об ака-

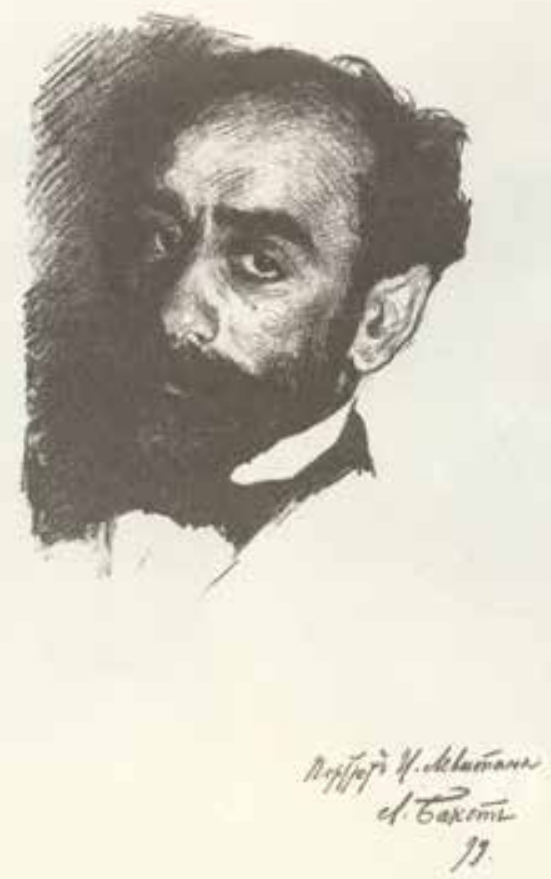

Илл. 2. Л.С. Бакст. «Портрет И.И. Левитана». 1899 г., 20,0 × 15,0 см. Бумага, литография // Частная коллекция

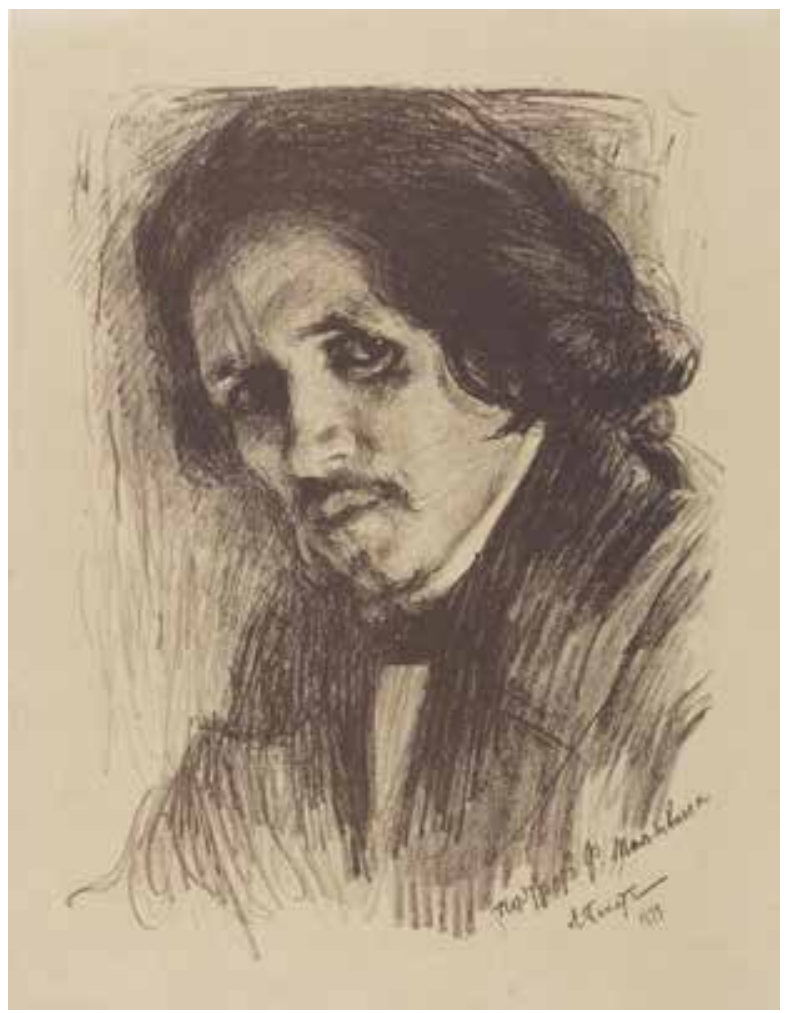

Илл. З. Л.С. Бакст. «Портрет Ф.А. Малявина». 1899 г., 36,0 × 28,0 см. Бумага, литография // Государственный Эрмитаж (Санкт-Петербург) демической выучке художника. В этих работах есть оттенок провинциальности, некоторой театральности, даже манерности. Колорит напоминает поздних академических мастеров и вызывает в памяти рассказ А.Н. Бенуа (1870-1960) об увлечении молодого Л.С. Бакста творчеством Г.И. Семирадского (1843-1902), Ю.Ю. Клевера (1850-1924) и К.Е. Маковского (1839-1915).

В 1893 году Л.С. Бакст уезжает в Париж, где в 1893-1896 годах занимается в студиях Жћ.-Л. Жерома и Р. Жюльена, а затем у финского художника Альберта Эдельфельта (1854-1905). Современники отмечали в его творчестве «французский шию» технического исполнения, который постарался перенять и его ученик [3, с. 10]. В Париже на молодого художника огромное впечатление производит творчество импрессионистов и главным образом французских романтиков. Л.С. Бакст внимательно изучает работы Э. Делакруа, Ораса Верне; он захвачен их мастерством, силой их колоризма. В поисках экзотики Л.С. Бакст предпринимает поездку в Алжир, повторяя путь Э. Делакруа. Это увлечение Востоком и представления о нем во многом предопределены ориентализмом форанцузских романтиков. Несколько акварелей, возникших в результате этой поездки, в т.ч. «Алжир» (1897) и «Вечер в окрестностях Эн-Сенфрура» (1897, ГТГ), очень декоративны [3, с. 11]. Эфрфектное сочетание красно-коричневого цвета песка и лилового в тенях во второй из них прямо навеяно недавними парижскими впечатлениями. Несмотря на то, что жизнь Л.С. Бакста в Париже была трудна, исполнена нужды и неуверенности в будущем, его работы уже получают первое одобрение критики (о творчестве молодого художника пишет И.Э. Грабарь).

Для Л.С. Бакста 1890-е годы - это не только время учения в Париже. Чрезвычайно важным для него становится знакомство с А.Н. Бенуа и его друзьями - будущими участниками объединения «Мир искусства», с которым была связана дальнейшая судьба Л.С. Бакста [3, с. 11]. Будучи старшим по возрасту и единственным Уже имеющим профрессиональное образование, Л.С. Бакст тем не менее очень легко вошел в кружок молодых людей, с необыкновенной гибкостью воспринял их взгляды и устремления и вскоре стал одним из самых активных деятелей кружка, а затем общества и журнала «Мир искусства» к изданию, которого, участники кружка приступили в 1898 году [3, с. 15]. Журнал за короткий срок завоевал признание - работы К.А. Сомова, Л.С. Бакста начинают воспроизводиться в немецких изданиях, в нем собирается сотрудничать Р.-М. Рильке (1875-1926). Участие Л.С. Бакста выражалось не только в создании собственно рисунков для журнала - как раз они в первые годы издания были немногочисленны, - но и в определении общей художественно-офрормительской линии журнала. Построение самого листа - соотношение шрифта, полей, расположение рисунков, текста, орнамента, виньеток, заставок, концовок - это дело его рук. В 1899-1901 годах несколько литографий Л.С. Бакста, Е.Е. Лансере, В.А. Серова и других художников объединения были помещены в качестве приложений к отдельным номерам журнала: «Мир искусства» [3, с. 18]. Работы Л.С. Бакста - портреты И.И. Левитана и Ф.А. Малявина 


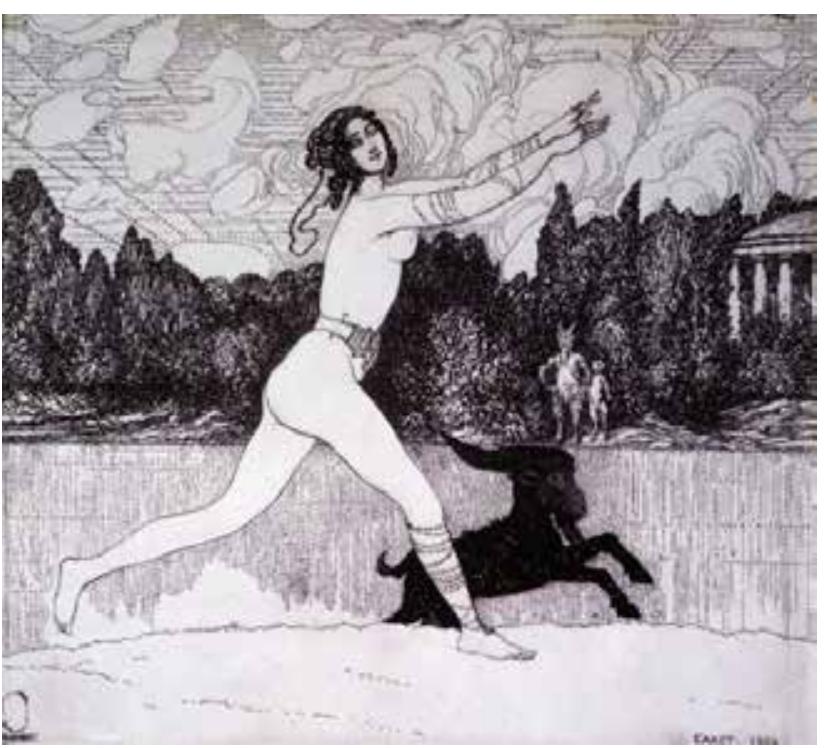

Илл. 4. Л.С. Бакст. «Античное видение». 1906 г. Бумага, тушь, перо, 16,1 × 17,9 см // Государственный Русский музей (Санкт-Петербург)

(1899), «Женский портрет» (1900), «Голова старухи» (1901) - отличаются свободой исполнения и уверенным профессионализмом [3, с. 18] (илл. 2, 3).

Лучшая из них - это литографированный портрет И.И. Левитана - поражает контрастностью сопоставления черного и белого. Живописный рисунок исполнен мелким, довольно коротким штрихом, выразителен не сам штрих, а масса пятна. Трехчетвертной разворот головы, расположение рисунка в верхней части листа, смещение центральной оси вносят оттенок беспокойства, подчеркивают трагический характер образа. Л.С. Бакстом также создана марка журнала, символически, выражавшая программу общества «Мир искусства» (в своем письме к А.Н. Бенуа он объясняет этот рисунок, который старался трактовать серьезно, как подразумевающую собой, аллегорическую картину) [3, с. 18]. Мотивы, характерные для собственно журнальной графики Л.С. Бакста, определяются очень рано и остаются почти неизменными на протяжении всей его деятельности. Преимущественно - это античные темы - буколические, пасторальные. В его виньетках часты изображения античных ваз, свисающих гирлянд, сосудов со спиралевидным орнаментом, фравнов, сатиресс, развалин храмов. Рокайльные мотивы также нередки в графике Л.С. Бакста. Великолепны по техническому совершенству контурные рисунки; они легки и изящны, словно кружевной узор, наброшенный на лист. Графическое оформление обычно не находится в тесной зависимости от текста. Орнаменты, взаимодействующие со шрифтом, окаймляющие лист целиком, заключающие текст в себя, у него редки, также нет сочных гнутых линий, орнаментов, созданных пятном. Линейность рисунка Л.С. Бакста явилась следствием воздействия графики О. Бёрдслея (1872-1898), сказывающегося в его творчестве в большей степени, чем у кого-либо из «мирискусников» [3, с. 22].

Созданный непосредственно под влиянием О. Бёрдслея, рисунок «Античное видение» (1906,

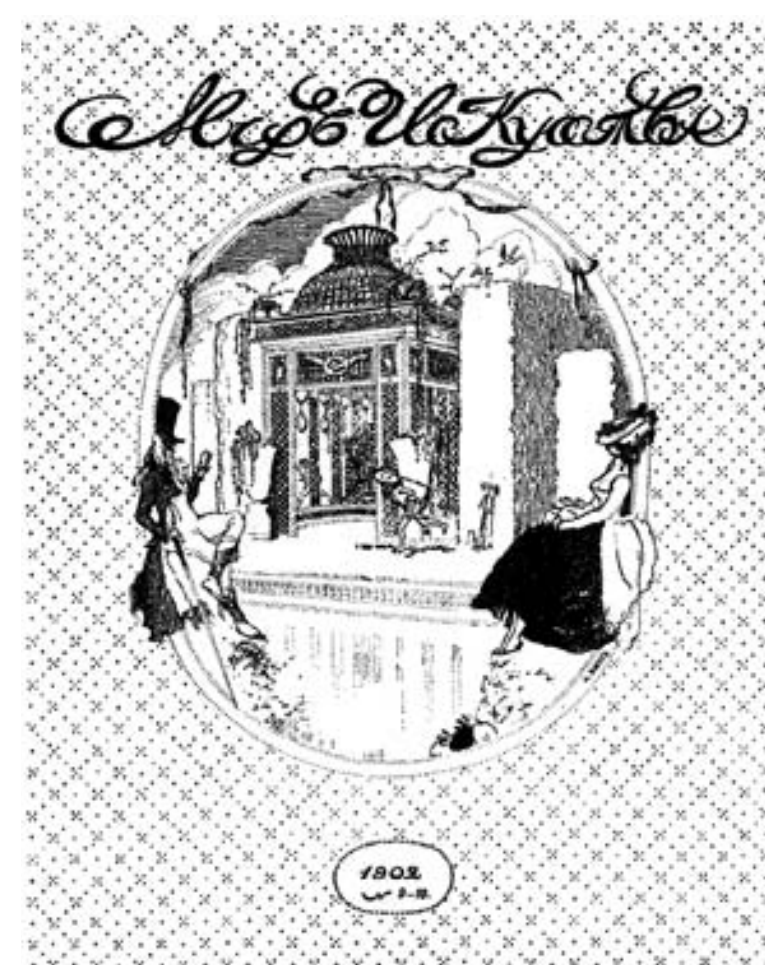

Илл. 5. Обложка журнала «Мир искусства» за 1902 г.

ГРМ) впечатляет свободой владения контуром, сопоставлением различных способов рисунка - гибкая линия, бисерный пунктир в рисунке облаков, темные заливки, штрихи пера [3, с. 22] (илл. 4).

Но, полностью контурными, плоскостными рисунки Л.С. Бакста назвать нельзя. Он не отказывается от штриховой моделировки, создающей впечатление объема, от пространственного мотива, который создается обычно обрамлением виньетки (колонны, круглая беседка) или введением в рисунок второго плана (обложка журнала «Аполлон» с бегущими сатирами, гонимыми звуками кифрары Аполлона) [3, с. 24]. Часто такой пространственный мотив создается двумя рисунками, которые сами по себе плоскостны, но один из которых заключен в другой, чем создается иллюзия пространственного отношения этих рисунков (обложка журнала «Мир искусства» за 1902 год) (илл. 5).

Этим же тяготением к объемности рисунка объясняется отсутствие силуэтов. В графике Л.С. Бакста можно видеть также следы воздействия работ Г. Фогелера, В. Дица, Т.Т. Гейне и даже $Ф$. Валлотона, что чувствуется, например, в заставке к стихам К.Д. Бальмонта («Мир искусства", 1901, № 5) [3, с. 24] (илл. 6).

Рисунок обнаженной женской фигуры сделан резким противопоставлением черных и белых пятен, без общей контурной линии, полутоновых переходов. Рисунок несет в себе не только сопоставление черного и белого, но и контраст резкого движения и статичного обрамления. Блестящая журнальная графика Л.С. Бакста современниками оценивалась достаточно высоко. Живописные же работы Л.С. Бакста публика могла видеть на выставках картин журнала "Мир искусства» [3, с. 27]. Уже на первую выставку, в 1899 году, Л.С. Бакст представил: «Портрет Александра Ни- 


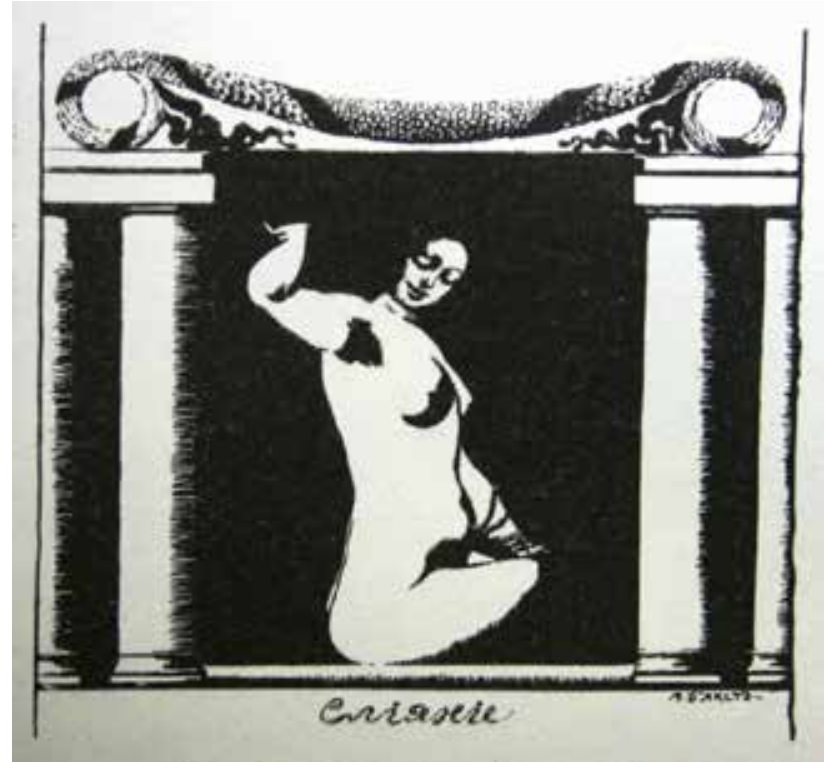

Илл. 6. Л.С. Бакст. «Заставка для журнала «Мир искусства»". 1901 г.

колаевича Бенуа» (1898, ГРМ) - один из лучших своих ранних портретов и одно из наиболее удачных изображений А.Н. Бенуа [3, с. 27] (илл. 7).

Этот портрет - одно из немногих изображений «человека в среде», что придает оттенок жанровости картине. Среда, окружение участвуют в создании образа человека, характеризуют его и не менее важны для сложения общего впечатления, чем лицо, или поза. Портрет выполнен пастелью, положенной очень пастозно, в выборе средств сказывается общий интерес «мирискусников» к графическим техникам [3, с. 27]. «Портрет филлософра В.В. Розанова» $(1901$, ГТГ) относится $\kappa$ той же группе портретов «в интерьере», но окружающие вещи играют меньшую роль и не в такой степени участвуют в создании образа портретируемого [3, с. 27] (илл. 8).

Сгорбленная фригурка с непомерно длинными руками словно бы внезапно появляется откудато снизу; быстрый взгляд маленьких глаз; общее впечатление юркости и подвижности. Портрет выполнен также пастелью в гамме очень легкой и светлой, написан очень свободно, так, что мож-

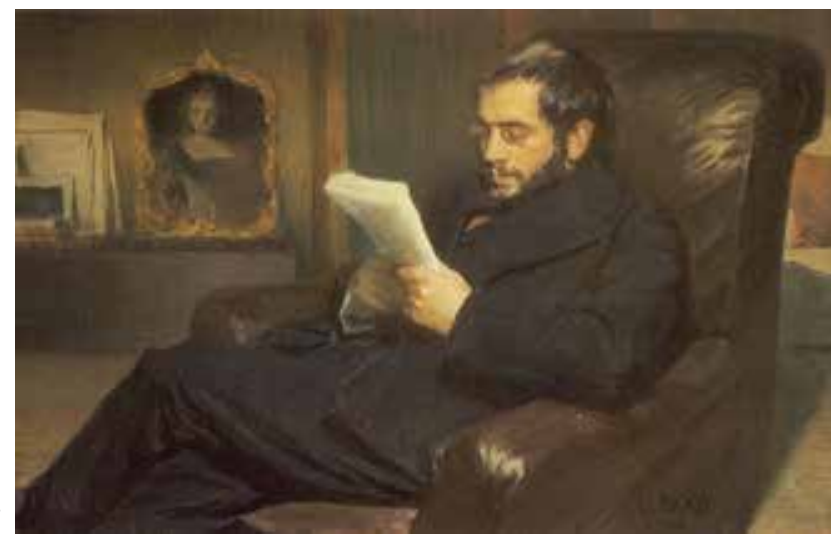

Илл. 7. Л.С. Бакст. «Портрет А.Н. Бенуа». 1898 г. Бумага, картон, акварель, пастель,

64,5 × 100,3 см // Государственный Русский музей (Санкт-Петербург) но увидеть направление штрихов. Работа возникла в период сближения Л.С. Бакста с В.В. Розановым (1856-1919), бывшим тогда сотрудником журнала "Мир искусства» [3, с. 28]. Хотя манера письма в портретах и А.Н. Бенуа и В.В. Розанова более подробна, чем в последующих работах, но во втором из них заметно уже тяготение к плоскостности и силуэтности построения. Эти качества нарастают в дальнейшем творчестве Л.С. Бакста. Другие работы этого времени - некоторые портреты, «В кафре» (ГТГ), «У жин» $(1902$, ГРМ) - словно бы воплощают, бытовавшее тогда представление о женщине модерна [3, с. 28] (илл. 9).

Существо загадочное, опасное, влекущее и околдовывающее, наделенное демонической красотой, - такова была маска женщины модерна. Подобную трактовку можно было встретить и у Л.С. Бакста, но чаще он «поэт кокотки и светской нарядницы», в его представлении женщина - греховная и очаровательная, прелестная и нарядная кукла, окруженная изысканной роскошью [3, с. 28]. «Ужин» - это едва ли не лучшая картина Л.С. Бакста, которая принесла ему успех и европейскую известность, после того, как была показана на выставке мюнхенского «Сецессиона» в 1903 году и воспроизведена на обложке журнала «Jugend» [3, с. 29].

Важно отметить, что оформление выставок стало своеобразной специальностью Л.С. Бакста, и он добился в этой области значительных достижений. Большим его успехом стало офрормление «Историко-художественной выставки русских портретов», устроенной в 1905 году С.П. Дягилевым (1872-1929) [3, с. 31]. Центральный зал Таврического дворца, где выставлялись скуль-

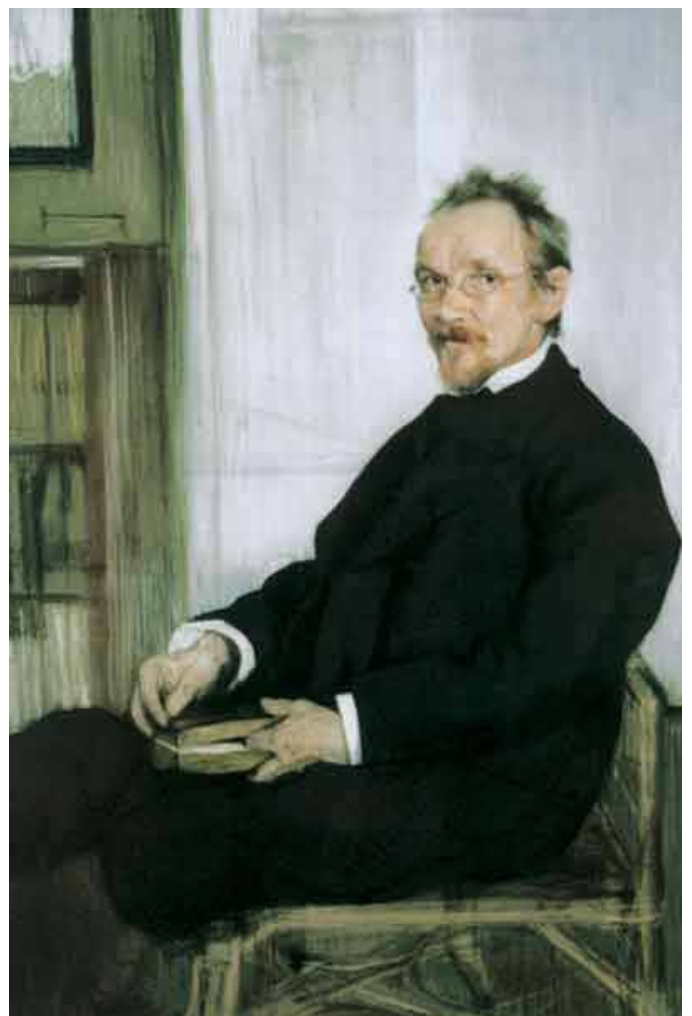

Илл. 8. Л.С. Бакст. «Портрет В.В. Розанова». 1901 г. Бумага серая, наклеенная на холст, пастель, 106,5 × 70,9 см // Государственная Третьяковская галерея (Москва) 
птурные портреты, был стилизован под уголок старинного парка во французском духе, скульптура смотрелась среди зелени. Подобно легким виньеткам, которые окружали листы с воспроизведениями старинных вещей в оформляемом Л.С. Бакстом издании «Художественные сокровища России», белые решетки, напоминающие трельяжи старинных беседок, разбивали зал, создавая собственное пространство для каждой скульптуры или группы скульптур [3, с. 32]. Значительно меньшее внимание Л.С. Бакст уделял офрормлению жилого интерьера. Известен только один подобный проект - это «Будуар», представленный на выставке "Современное искусство», в которой принимали участие А.Я. Головин, К.А. Коровин, А.Н. Бенуа, Е.Е. Лансере [3, с. 35]. «Будуар», созданный по рисунку Л.С. Бакста, это овальная, очень светлая комната [3, с. 35]. Дверь и большое окно с большим переплетом расположены друг против друга и обрамлены одинаковыми пилонами; наверху на пилонах рельефы - спящие путти. Решетка спинок кресел и стульев напоминает плетение парковых беседок. В рисунке мебели преобладают строгие геометрические линии и пересечения под прямым углом, контрастирующие с изгибом стен. Орнамент очень сдержан, его немного - легкий рисунок паркета, повторяющийся в декоре камина и тиснения на кожаных сиденьях. Игра пространства в круглении стен и зеркальных отражениях. Особое внимание обращено на тщательность и чистоту отделки. В самой необычайной нарядности и артистизме этой отделки есть что-то неестественное, не для человека созданное - любой человек показался бы грубым и неуместным в этом изысканном интерьере, нарушил бы атмосферу тонкой, изящной игры.

Свою деятельность в качестве художника интерьера Л.С. Бакст продолжал довольно долго. По воспоминаниям современников, известно, что Л.С. Бакст офрормлял некоторые интерьеры в Англии и часто декорировал помещения, которые С.П. Дягилев снимал для проведения спектаклей своей антрепризы (об одном из таких случаев, происшедшем во время гастролей в Англии, упоминает русская артистка балета - Т.П. Карсавина в своих записках 1971 года «Театральная улица») [3, с. 38]. Можно отметить, что Л.С. Бакст обращает внимание, прежде всего, на цветовое решение интерьера, а не на необычную организацию пространства - для признанного мастераколориста, художника, не имевшего архитектурной практики, это было естественно. Позже, на характер интерьеров влиял опыт театральной практики, привычка работать с традиционным единым и нерасчлененным сценическим пространством. Отсюда же и основные принципы офрормления интерьеров Л.С. Бакста - театрализация, стилизация. Это объясняется и характером его дарования, и типом, оформляемых им интерьеров, наделенных особым, приподнятым настроением, - театр, выставка, залы для балов и маскарадов. Уделяя внимание живописи и офрормлению интерьеров, Л.С. Бакст не менее интенсивно продолжает работать и в других жанрах. Следует коснуться сотрудничества Л.С. Бакста в сатирических журналах первой русской революции. Л.С. Бакст работает в жур-

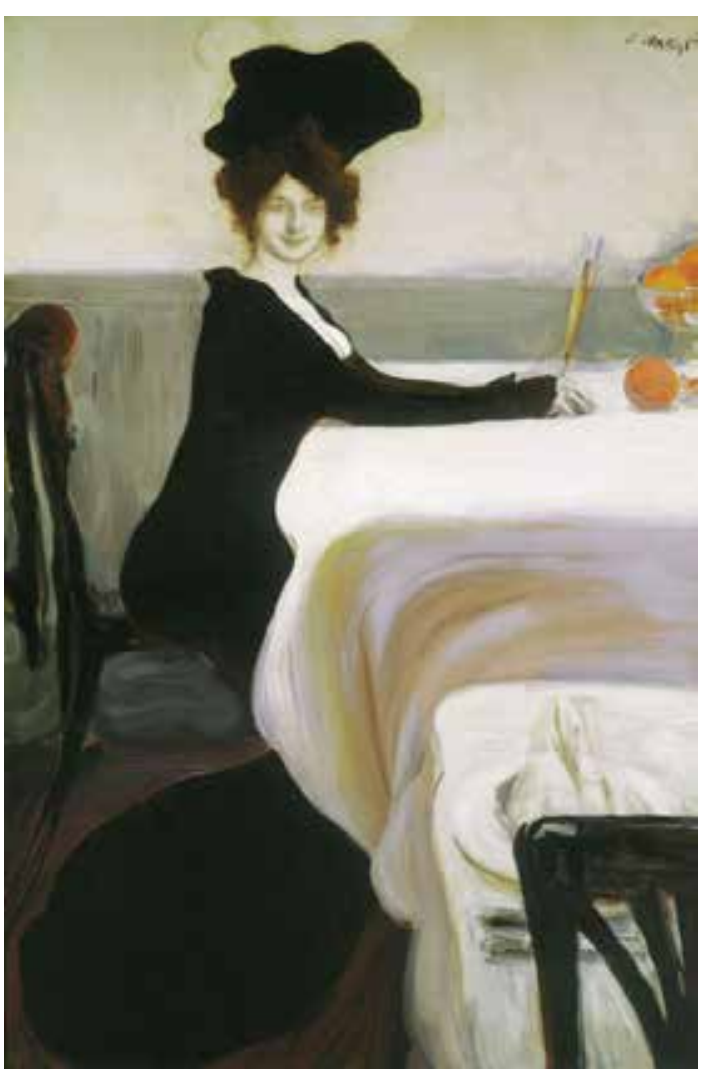

Илл. 9. Л.С. Бакст. «Ужин». 1902 г. Х., м., $150,0 \times 100,0$ см // Государственный Русский музей (Санкт-Петербург)

нале «Зритель» и, как многие художники: «Мира искусства», принимает участие в «Жупеле» - самом известном из журналов 1905 года [3, с. 41]. Руководимый художником З.И. Гржебиным, «Жупел» объединил вокруг себя многих видных художников, в т.ч. и Б.И. Анисфельда, И.Я. Билибина, И.Э. Грабаря, А.П. Остроумову-Лебедеву, К.А. Сомова и др. [3, с. 41]. ЖАрнал должен был стать своего рода русским «Симплициссимусом» (это единство с изданием, до тех пор, запрещенному в России, декларировалась в первом же номере журнала) [3, с. 41]. Л.С. Бакст занимался, в основном, общим офрормлением журнала. Сатирическую линию в творчестве художника, порожденную участием в революционных изданиях, можно было проследить в дальнейших работах для журнала “Сатирикон» (рисунки цикла «Гримасы») [3, с. 42].

В станковой живописи Л.С. Бакста 1900-х годов, по-прежнему, центральное место занимает портрет, жанр, к которому остальные «мирискусники», за исключением В.А. Серова и К.А. Сомова, обращались редко [3, с. 42]. «Портрет С.П. Дягилева с няней» (1906, ГРМ), подобно ранним портретам А.Н. Бенуа и В.В. Розанова, продолжает галерею изображений людей, близких Л.С. Баксту [3, с. 42] (илл. 10).

В этом портрете контрастно сопоставлены два возраста, две фригуры, два состояния - спокойная, уютная старушка, нежно любимая всеми друзьями С.П. Дягилева и бывшая для них своей Ариной Родионовной, и сильная, энергичная фоигура С.П. Дягилева, вскинувшего голову с эффректной седой прядью. В портрете подчеркивается дягилевская уверенность в себе, скрытая 
энергия человека, так быстро, сумевшего стать одной из центральных фригур: “Мира искусства», редактором журнала, деятельным организатором выставок и прославленным создателем: «Русских балетов» в Париже (много лет сотруд-

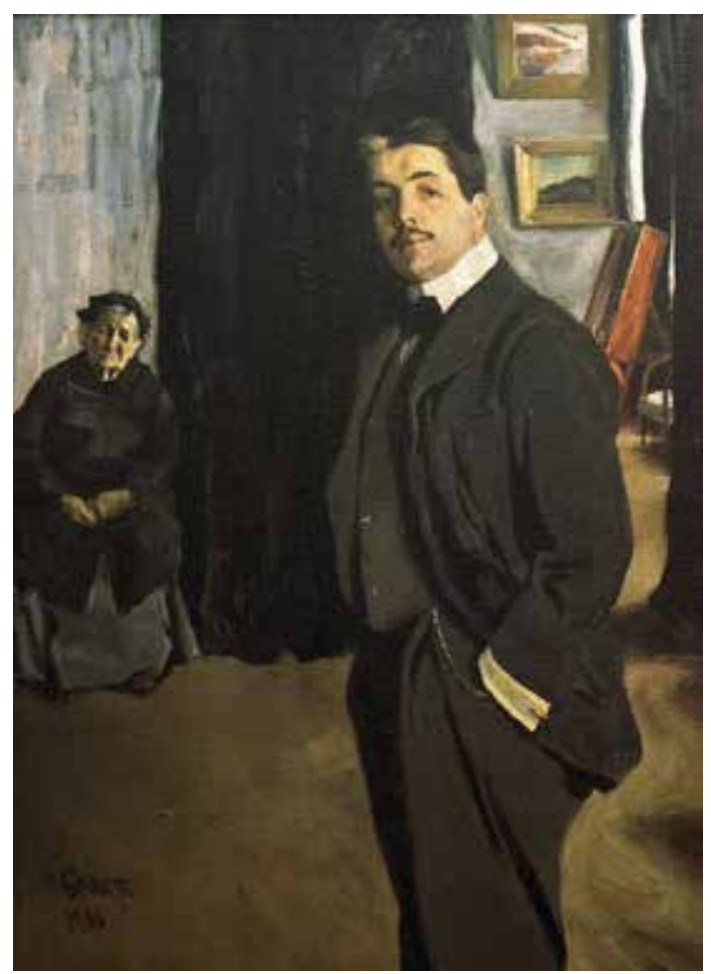

Илл. 10. Л.С. Бакст. «Портрет С.П. Дягилева с няней». 1906 г. Х., м., 161,0 × 116,0 см // Государственный Русский музей (Санкт-Петербург)

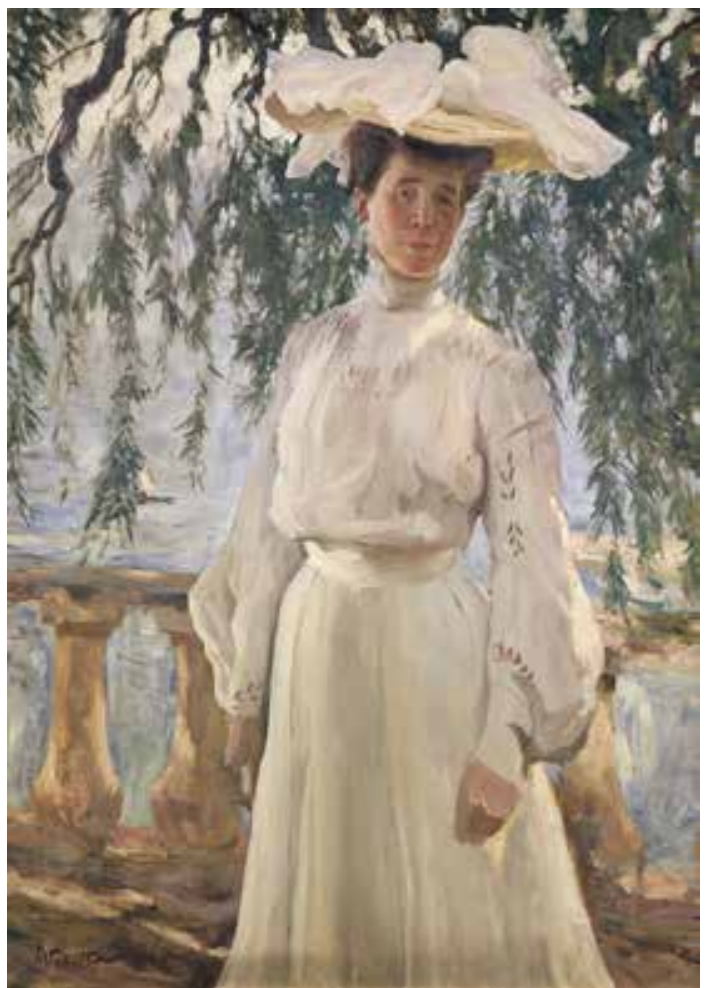

Илл. 11. Л.С. Бакст. «Портрет Л.П. ГриценкоБакст". 1903 г. Холст, масло // Государственная Третьяковская галерея (Москва) ничал с С.П. Дягилевым по «Русским балетам и сам Л.С. Бакст) [3, с. 44]. Силуэтное, плоскостное восприятие модели сохраняется в пленэрных работах. Ветви дерева ограничивают пространство, создают фон для фригуры в портрете жены Любови Павловны Гриценко-Бакст, урожденной Третьяковой (1903, ГТГ) (илл. 11).

Равнодушие к пространственным отношениям заметно и в «Портрете великой княгини Елены Владимировны» (1899, Государственный музей искусств Казахстана имени А. Кастеева), ярком, декоративном, построенном на эфрфектном сочетании ярко-красного с белым костюма и темной осенней зелени [3, с. 46]. В портрете 3.Н. Гиппиус в мужском костюме $(1906$, ГТГ) манера рисунка, поза, костюм подчеркивают красоту и экстравагантность модели (илл. 12).

Артистизм владения техникой находит здесь свое полное выражение Жирная диагональная штриховка, тонкая растушевка черного карандаша, свободные штрихи мелом в рисунке жабо и манжет воспроизводят фрактуру бархата, шелка. Желтоватая бумага, мел. Приобретающий на ней тонкий розовато-сиреневый оттенок, черные линии карандаша, рыжий цвет волос - рисунок эфрфектен и красив. «Великолепным и дерзковыразительным» назвал его С.К. Маковский (1877-1962) [3, с. 48]. В серии графических портретов, созданной Л.С. Бакстом в 1906 году, используется сомовская схема портрета, в которой все внимание концентрировалось на лице и лишь легким абрисом намечалась фригура. Л.С. Бакст разрабатывает эту схему, как уже, найденный другим готовый образец, чувствуя, что она отвечает существующему стилю, но использует ее, может быть, еще менее сознательно, чем К.А. Сомов. Сомовский портрет шире, чело-

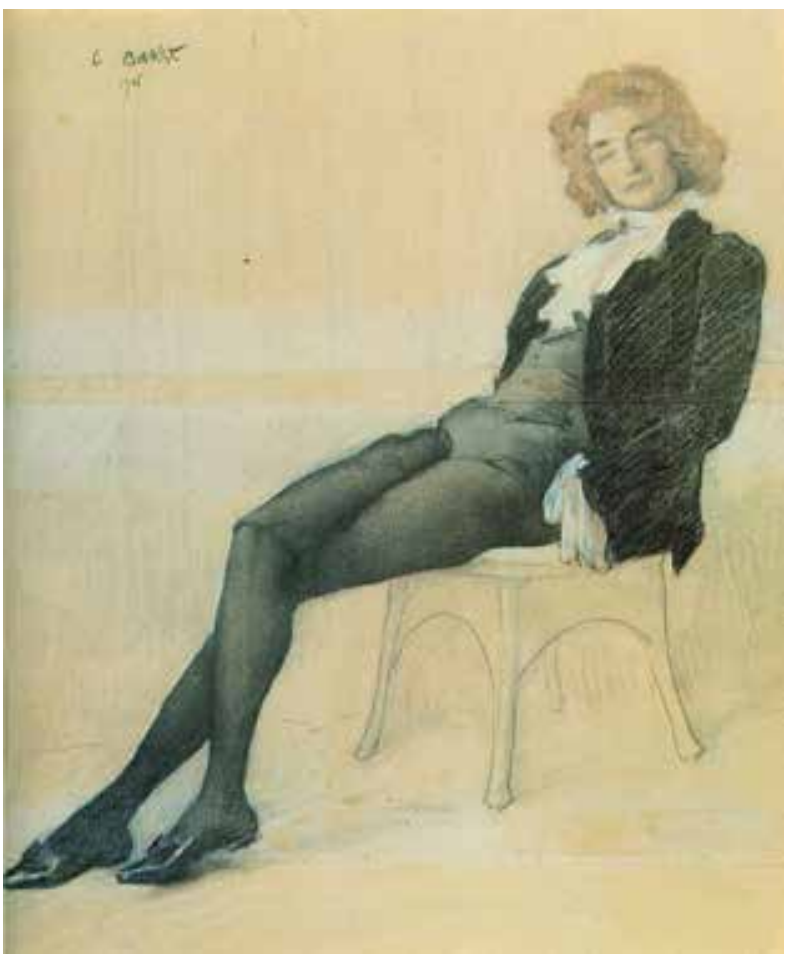

Илл. 12. Л.С. Бакст. «Портрет Зинаиды

Гиппиус». 1906 г. Бумага, пастель, 54,6 × 49,0 см // Государственная Третьяковская галерея (Москва) 


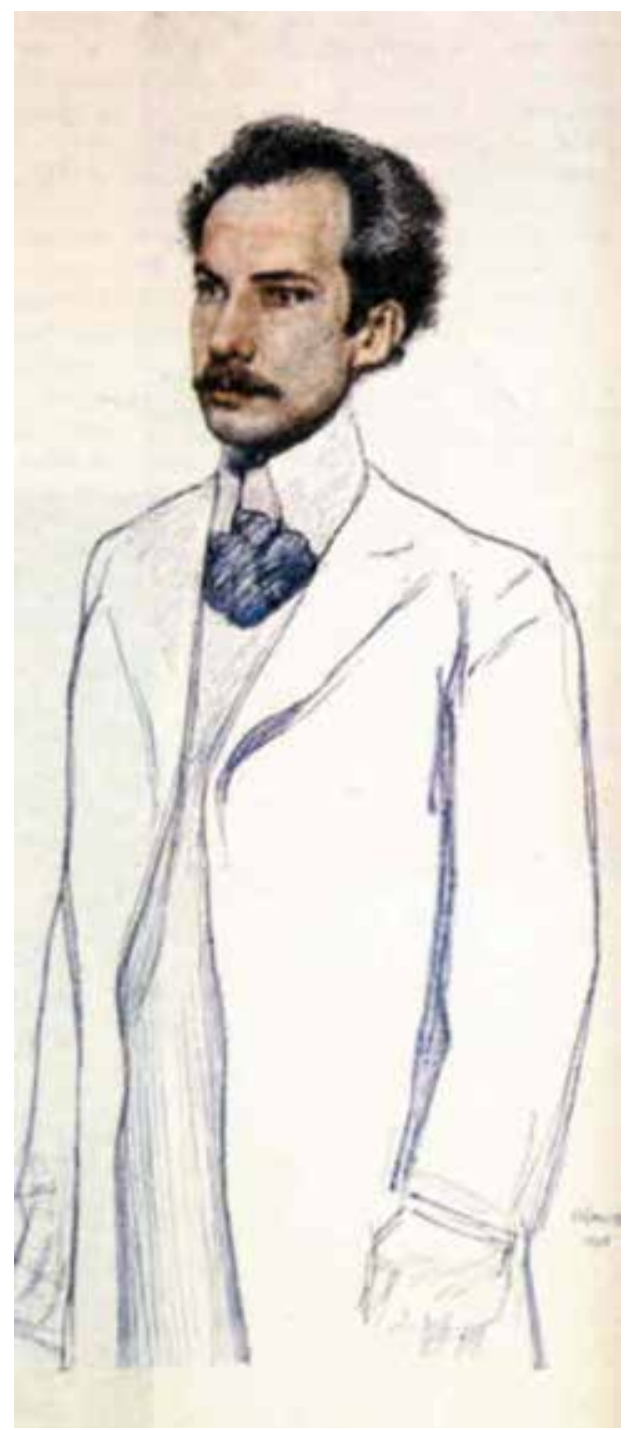

Илл. 13. Л.С. Бакст. «Портрет Андрея Белого». 1906 г. Бумага, цветной карандаш // Государственный Русский музей (Санкт-Петербург)

век в нем предстает лишь в одном из своих образов, скрывая, предполагаемые другие, и тем самым истолковывается многозначно.

Л.С. Бакст воспринимает систему К.А. Сомова, прежде всего, как формальную схему исполнения. Его привлекает контраст детализированной проработки и контура, художник прекрасно чувствует эфрфектность такого противопоставления и большие возможности этого портретного принципа. Серия новых портретов продолжает ранние работы Л.С. Бакста, нисколько не противореча им внутренне. В них нет отказа от характеристики, присутствует большая наблюдательность, которой отличался Л.С. Бакст. Портреты не воспринимались им полностью, как портретмаска - Л.С. Бакст не отказывается от изображения жеста, некоторые из портретируемых даны в трехчетвертном повороте - такой прием подчеркивает объемное построение и обычно дает намек на конкретное окружающее пространство. Bсе работы выполнены карандашом, подцвечены. Для подцветки употребляются, часто в комбинации, уголь, мел, сангина, цветные карандаши (на примере его работ: «Портрета Андрея

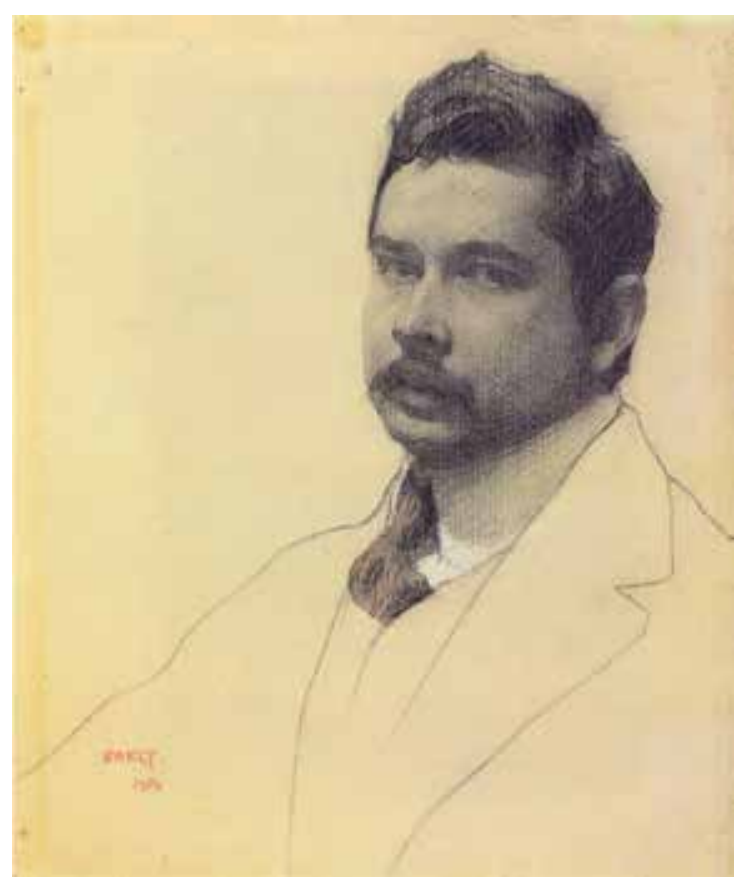

Илл. 14. Л.С. Бакст. «Портрет К.А. Сомова».

1906 г. Бумага, карандаш, уголь, цветной карандаш, мел, 32,0 × 26,0 см // Государственная Третьяковская галерея (Москва)

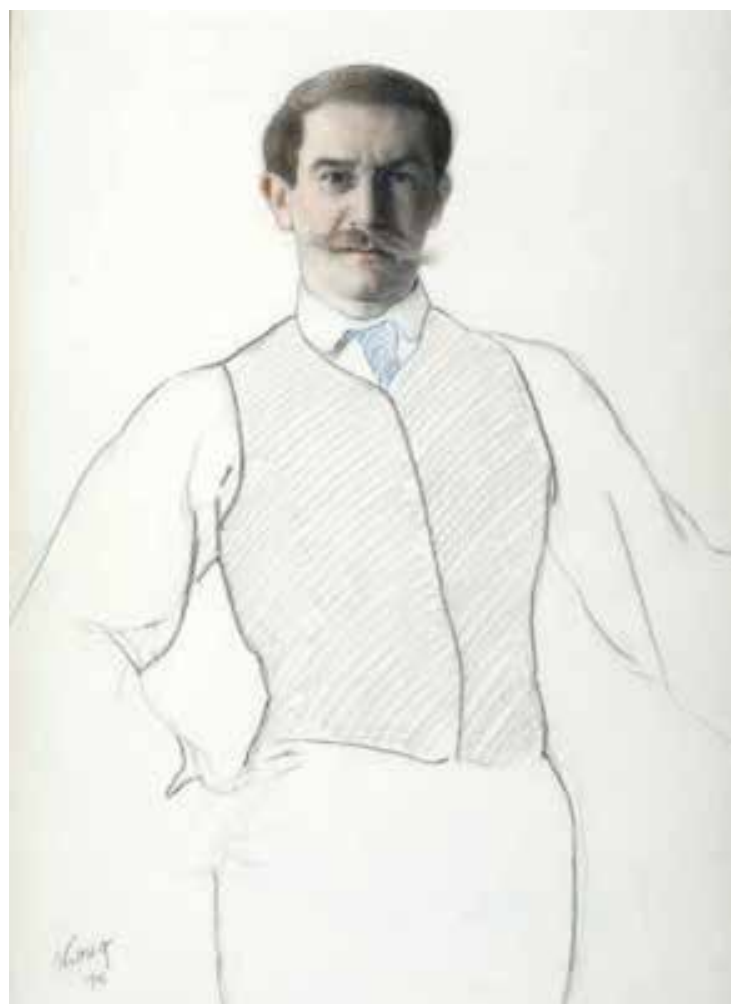

Илл. 15. Л.С. Бакст. «Автопортрет». 1906 г.

Бумага, картон, уголь, сангина, цветной карандаш // Государственная Третьяковская галерея (Москва)

Белого, 1905; «Портрета К.А. Сомова», 1906; «Автопортрета», 1906 и др.) [3, с. 50] (илл. 13, 14, 15).

Эскизы костюмов Л.С. Бакста к балетным постановкам вызывают всеобщее восхищение. «В этой области Л.С. Бакст, - писал А.Н. Бенуа, с первых шагов (еще в России, еще при постанов- 


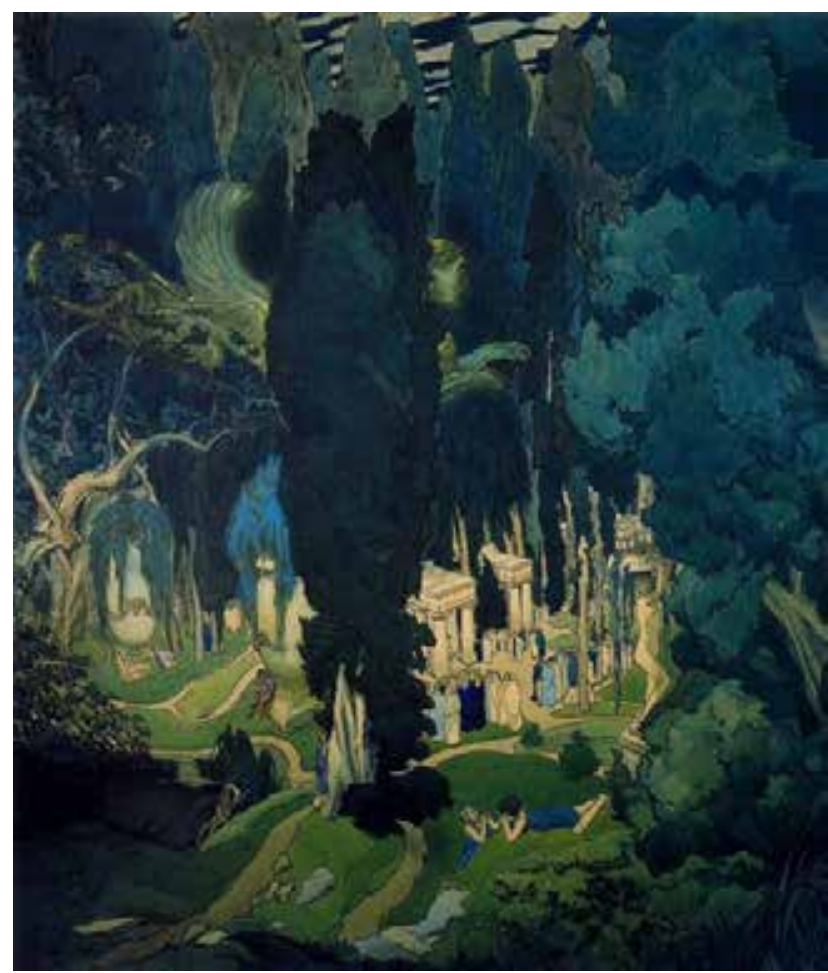

Илл. 16. Л.С. Бакст. «Элизиум». 1906 г. Бумага, акварель, гуашь, $158,0 \times 40,0$ см //

Государственная Третьяковская галерея (Москва)

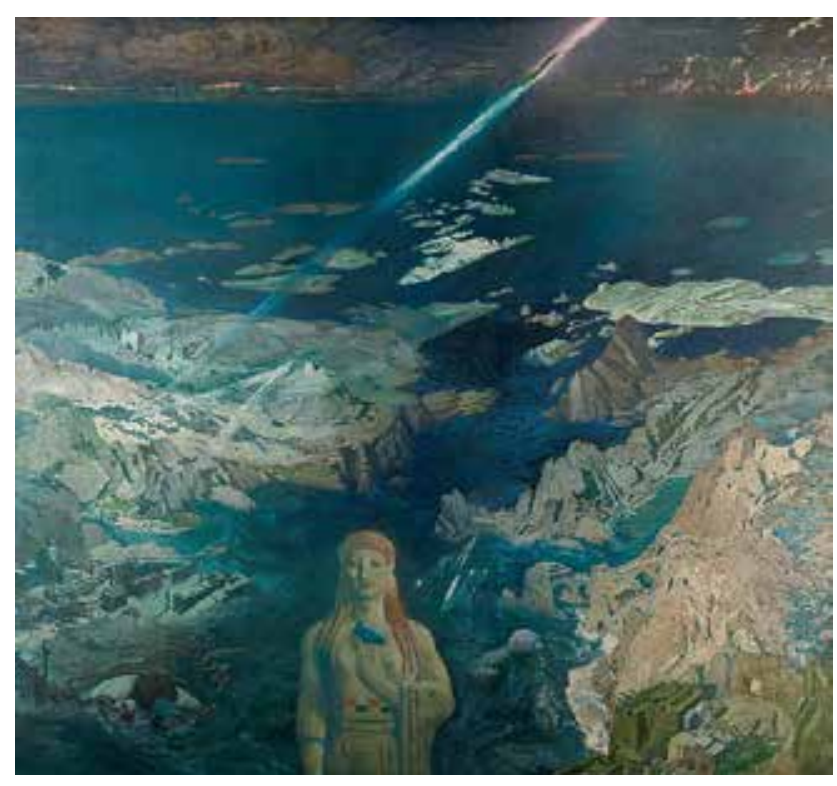

Илл. 17. Л.С. Бакст. «Древний ужас (Terror Antiquus)». 1908 г. Х., м., 250,0 × 270,0 см // Государственный Русский музей (Санкт-Петербург)

ке: «Сердца маркизы» и «Феи кукол» занял прямотаки главное положение и с тех пор так и остался единственным и непревзойденным...» [3, с. 64]. Л.С. Бакст в своих эскизах рисует не кукольную одежду для балерин, его рисунки - это рисунки кукол и ни в коей мере не рисунки манекенов в нужном костюме с подробными указаниями портному; это вообще не рисунки для портного. Для Л.С. Бакста-декоратора не были характерны (и встречаются только в начале деятельности) ри-

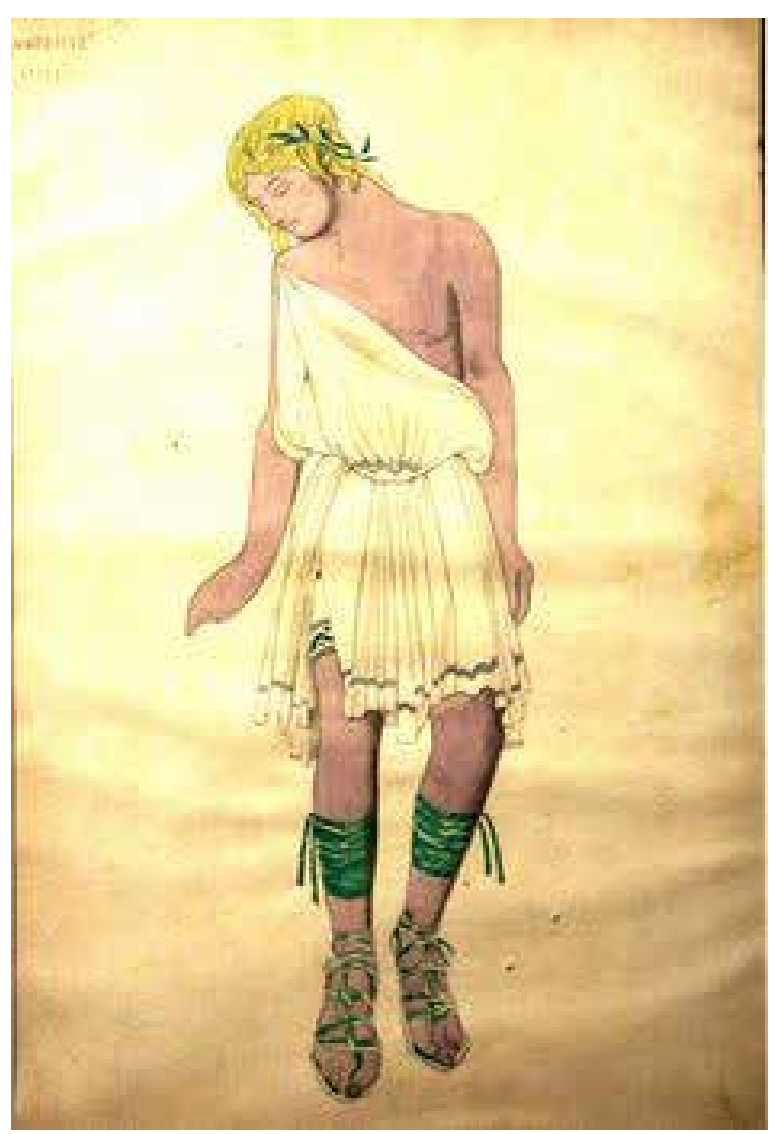

Илл. 18. Л.С. Бакст. «Нарцисс». Эскиз декорации к балету Н. Черепнина «Нарцисс». 1911 г. Бумага, карандаш, серебро, золото

сунки персонажей в костюмах, данные в нескольких поворотах, с пометками, объясняющими портному покрой, испещренные мелкими деталями, прорисовками орнаментов, аксессуаров.

Эскизы Л.С. Бакста сразу же приобретают ценное значение. Сценические рисунки Л.С. Бакста можно рассматривать, как графическую серию, они приобретают самостоятельную жизнь, воспроизводятся на открытках, экспонируются на выставках, интересны безотносительно к спектаклю и позволяют говорить о сценической графике Л.С. Бакста, как о своеобразном жанре. Л.С. Баксту принадлежало также оформление нескольких спектаклей на античную тему (первой работой, связанной с античностью, стала постановка пьесы Еврипида «Ипполит», в переводе Д.С. Мережковского, на сцене Александринского театра; следующая постановка, оформленная Л.С. Бакстом, - это "Эдип в Колоне» Софокла) [3, с. 68]. Тема античности настолько захватила Л.С. Бакста, что стала надолго одной из ведущих и существенных в его творчестве. Будучи в драматическом театре, скованным волей режиссера и материалом самой пьесы, он выражает свое понимание античности в многочисленных станковых работах («Элизиум», 1906; «Древний ужас», 1908 и др.) [3, с. 70] (илл. 16, 17).

Картина, эта созданная под впечатлением мифра об Атлантиде, принесла Л.С. Баксту большой успех на выставке в Париже. Но, друзьями художника она была оценена скромнее, А.Н. Бенуа назвал ее "надуманной диссертацией» [3, с. 76]. Л.С. Бакст представляет панораму, гиб- 
нущего мира - еле различимы мечущиеся люди, огромные идолы кажутся издали маленькими игрушками; отвернувшись от рушащегося мира смотрит на зрителя статуя Афрродиты с застывшей архаической улыбкой. Картина - это изображение, зрелище мировой катастрофы; зритель отрешен от переживания, происходящего самим пространственным построением, подчеркиваюшим временную отдаленность события-легенды, настолько туманного и отстраненного от реальной истории, что драма не может волновать и вызывать сострадание. Но, все же античная тема, порожденная театром, разрешалась естественнее в театре. К сожалению, слишком не часты были эти театральные работы, даже несмотря на то, что, по единодушному мнению, Л.С. Бакст именно в театре наконец «нашел себя», именно здесь пригодились его вкус, образованность и тонкое знание эпох [3, с. 80]. Античная тема в театральном творчестве Л.С. Бакста по-прежнему занимала значительное место, продолжаясь балетами «Нарцисс», «Дафрнис и Хлоя», «Послеполуденный отдых фравна» [3, с. 92] (илл. 18).

В первых двух балетах развивалась тема античной буколики. Несмотря на то, что судьбу героев первого балета решали снова рок, гнев и проклятие богов, он был лишен ощущения трагичности. Это было зрелище эстетизированное и изысканное, соответствующее музыке - утонченной и несколько вычурной. Совместная работа с Вацлавом Нижинским (1889-1950) над балетом: «Послеполуденный отдых фравна", открывшим путь к новому экспрессионистическому балету, позволяла Л.С. Баксту перейти к новому пониманию архаики и классики, присущему уже XX веку. Сотрудничество Л.С. Бакста с В. Нижинским - это еще одно свидетельство чуткости художника к новому, позволившее ему дольше всех остальных художников «Мира искусства» работать с С.П. Дягилевым [3, с. 94].

Таким образом, процесс становления Л.С. Бакста, как художника был очень сложен; манера его, складываясь в течение долгого времени, претерпела множество изменений. В новый, 1924 год он вошел, переполненный новыми, и как всегда, грандиозными идеями. Ему давно хотелось открыть Дом моды. Театральные одежды, интерьер, мебель, посуду, даже ювелирные украшения Л.С. Бакст вознамерился создавать сам. Но, силы были на исходе. Летом 1924 года на репетиции балета «Истар» с Идой Рубинштейн в главной роли (в оформлении и по сценарию Л.С. Бакста) мастера настиг нервный припадок, на пять месяцев, уложивший его в постель [2, с. 5]. В результате долгой бездвижности развился отек легких, и 27 декабря того же года Л.С. Бакст умер. Похоронили его при огромном стечении народа на парижском кладбище Батиньоль.

\section{Список литературы:}

1. Байгузина Е.Н. Л.С. Бакст: В поисках античности. СПб. : «Нестор-История», 2009. 206 с.: ил.

2. Бакст / Художественная галерея. Полное собрание работ всемирно известных художников. 2008. Вып. 187. 31 с.

3. Борисовская Н.А. Лев Бакст. Москва : «Искусство», 1978. 120 с.: ил.

4. Голынец С.В. Лев Самойлович Бакст. Москва : ООО «БуксМАрт», 2017. 408 с.

5. Лев Бакст. 1866-1924. Альманах. Вып. 470 / Авт. ст. и летописи жизни и творчества В. Круглов / Государственный Русский музей. СПб. : «Palace Editions», 2016. 144 с.

6. Лев Бакст / Авт. текста: Л. Жукова. Москва : «Белый город»; «Воскресный день», 2018. 3 с.: ил. (Большая художественная галерея).

7. Пружан И.Н. Лев Самойлович Бакст. Ленинград : «Искусство», 1975. 232 с.

\section{References:}

1. Bajguzina E.N. (2009). L.S. Bakst: V poiskah antichnosti. SPb. : «Nestor-Istorija», 206 p.: il.

2. Bakst / Hudozhestvennaja galereja. Polnoe sobranie rabot vsemirno izvestnyh hudozhnikov. 2008. Vyp. 187. 31 p.

3. Borisovskaja N.A. (1978). Lev Bakst. Moskva : «Iskusstvo», 120 p.: il.

4. Golynets S.V. (2017). Lev Samoilovich Bakst. Moskva : LLC "BuxMart”, 408 p.

5. Lev Bakst (2016). 1866-1924. Al'manah. Vyp. 470/Avt. st. i letopisi zhizni i tvorchestva V. Kruglov/Gosudarstvennyj Russkij muzej. SPb. : «Palace Editions», 144 p.

6. Lev Bakst (2018). Avt. teksta L. Zhukova. Moskva : «Belyj gorod»; «Voskresnyj den'», 3 p.: il. (Bol'shaja hudozhestvennaja galereja).

7. Pruzhan I.N. (1975). Lev Samojlovich Bakst. Leningrad : «Iskusstvo», 232 p. 